\title{
FPC RATEMAKING: JUDICIAL CONTROL OF ADMIINISTRATIVE PROCEDURAL FLEXIBILITY
}

The Natural' Gas Act (NGA) authorizes the Federal Power Commission (FPC) to establish "just and reasonable" rates for the interstate sale and transportation of natural gas. ${ }^{1}$ Traditionally, the Commission has set rates in the context of trial-type adjudicatory proceedings. Recently, however, it has sought to abandon this method in favor of a more streamlined informal rulemaking proceeding which, unlike an adjudicatory proceeding, is not conducted on the record and does not afford an opportunity for cross-examination. The validity of this streamlined procedure was challenged in two 1973 cases which reached conflicting conclusions. In Phillips Petroleum Co. v. FPC, ${ }^{2}$ the Court of Appeals for the Tenth Circuit sustained the new informal rateinaking procedures, holding that the Commission was not bound by its former use of adjudication and that it could utilize informal rulenaking proceedings in establishing rates. In contrast, the Court of Appeals for the District of Columbia Circuit held in Mobil Oil Corp. v. $F P C^{3}$ that informal rulemaking procedures are insufficiently adversary in nature to create a record that can adequately support the factual findings of the Commission and thus permit judicial review.

This Note will examine the question of whether the FPC may establish rates pursuant to informal rulemaking procedures. Initially, it will briefly trace the evolution of FPC ratemaking procedures and thereafter it will examine the statutory franework and the judicial precedents which underlie the issue of the proper procedures to be einployed in FPC ratemaking. Finally, it will compare the contrasting opinions in Phillips and Mobil in order to ascertain the validity of the FPC's new approach to ratemaking.

\section{Evolution of FPC Ratemaking Procedures}

The shift from adjudicatory to informal rulemaking procedures is part of a long-standing effort by the FPC to expedite its ratemaking process. ${ }^{4}$ When the NGA was enacted in 1938, the Commission de-

1. 15 U.S.C. $\$ 717 c(a)$ (1970). Rates which the FPC determines not to be "just and reasonable" are to be declared "unlawful." Id. 1974).

2. 475 F.2d 842 (10th Cir. 1973), cert. denied, 42 U.S.L.W. 3401 (U.S. Jan. 14,

3. 483 F.2d 1238 (D.C. Cir. 1973).

4. Phillips Petroleum Co., 24 F.P.C. 537, $545-46$ (1960); Dakin, Ratemaking as Rulemaking-The New Approach at the FPC: Ad Hoc Rulemaking in the Ratemaking Process, 1973 Duke I.J. 41, 48. 
termined that its ratemaking authority extended only to the then less than $200^{5}$ pipeline companies engaged in the interstate transportation and resale of natural gas. ${ }^{6}$ In exercising this ratemaking authority, the FPC established rates for each company on an imdividual basis, affording each pipeline company an evidentiary hearing. ${ }^{7}$ In the 1954 decision of Phillips Petroleum Co. v. Wisconsin, ${ }^{8}$ the Supreme Court held that the Commission's authority also included the several thousand ${ }^{9}$ independent producers of natural gas who were engaged in selling gas to pipeline companies but not in transporting and reselling it in interstate commerce. ${ }^{10}$ The immediate result of this decision was a staggering increase in the FPC's workload. ${ }^{11}$ The Commission atteinpted to continue its practice of establishing rates on a company-by-company basis, but this method required the FPC to

5. Dakin, supra note 4 , at 48 .

6. In The East Ohio Gas Co., 1 F.P.C. 586 (1939), the Commission first determined that it had jurisdiction to regulate natural gas pipeline companies engaged in the transportation and sale of natural gas in interstate commerce. Id. at 591-92. See also Illinois Commerce Comm'n v. Natural Gas Pipeline Co., 2 F.P.C. 218, 223-24 (1940). However, the Commission determined and maintained through a series of cases ended by the 1954 decision of Phillips Petroleum Co. v. Wisconsin, 344 U.S. 672 (1954), that its jurisdiction did not extend to mere producers of natural gas. See, e.g., Phillips Petroleun Co., 10 F.P.C. 246, 262, 282-83 (1951); Columbian Fuel Corp., 2 F.P.C. 200 (1940). The effect of this line of cases was to limit the Commission's ratesetting authority under the NGA to interstate pipeline companies. But see Interstate Natural Gas Co., 3 F.P.C. 416, $418-20$ (1943), aff'd, 156 F.2d 949 (5th Cir. 1946), aff'd, 331 U.S. 682 (1947) (extending FPC jurisdiction to a producer who had avoided state jurisdiction by contending that $99 \%$ of its sales were in interstate commerce).

For discussions of the history of FPC ratemaking under the NGA, see Dakin, supra note 4; Yost \& Riggs, Practice and Procedure Before the Federal Power Commission, 14 Geo. WaSh. L. REv. 114 (1945). See generally Bagge, The Federal Power Commission, 11 B.C. IND. \& CoM. L. REv. 689 (1970).

7. See, e.g., City of Cleveland v. Hope Natural Gas Co., 3 F.P.C. 150, 154 (1942), rev'd on other grounds, 134 F.2d 287 (4th Cir. 1943), rev'd 320 U.S. 591 (1944).

8. 347 U.S. 672 (1954).

9. Although the Supreme Court did not specify the number of producers that would be affected by its holding in Phillips, a subsequent hearing conducted by the FPC established that several thousand producers would fall within the scope of that decision. Phillips Petroleum Co., 24 F.P.C. 537, 545 (1960).

10. 347 U.S. at 685 . The Commission had previously always held that its jurisdiction did not extend to producers. See note 6 supra.

11. The FPC was reluctant to assume the responsibilities assigned to it as a result of the holding in Phillips $v$. Wisconsin since it feared that regulation of producers would prove impractical. Cf. 39 F.P.C. ANN. REP. 12-13 (1959); 37 F.P.C. ANN. REP. 17-18 (1957); 36 F.P.C. ANN. REP. 10 (1956); 35 F.P.C. ANN. REP. 176-77 (1955). The FPC's unfavorable attitude toward the extension of its jurisdiction in Phillips is reflected in the Commission's positive discussion of proposed legislation which would have exempted producers from its regulation. See 36 F.P.C. ANN. REP. 10 (1956); 35 F.P.C. ANN. REP. 176-77 (1955). 
repeat lengthy hearings for each independent producer in the nation. It soon became apparent that regulation of such producers placed an intolerable straim on the FPC's resources and effectively frustrated the Commission's regulatory task. ${ }^{12}$ Consequently, instead of estabhishing rates for each gas producer, the Commission in 1960 adopted area ratemaking procedures by which it required all producers within designated national regions to observe maximum rates promulgated for each region. ${ }^{13}$ In this way, the Commission reduced from several thousand to only seven the number of ratemaking procedures it conducted. ${ }^{14}$ In light of this drastic reduction in its caseload, the Commission continued its practice of fixing rates in the context of an adjudicatory hearing. ${ }^{15}$ The initial application of these new procedures, which lasted five years, ${ }^{16}$ involved the establishing of rates for the Permian Basin

12. Setting rates in this manner became so inefficient following the Phillips $v$. Wisconsin decision that six years later FPC regulation was termed the "outstanding example in the federal government of the breakdown of the adininistrative process." J. Landis, Report on Regulatory Agencies to the President-Elect 54 (1960). One court has noted that individual ratemaking had resulted in the FPC's "resources being exhausted more rapidly than the gas under scrutiny." Placid Oil Co. v. FPC, 483 F.2d 880, 885-86 (5th Cir. 1973), cert. granted sub nom. Mobil Oil Corp. v. FPC, 42 U.S.L.W. 3405 (U.S. Jan. 15, 1974) (No. 73-437).

After the remand of the Phillips v. Wisconsin case in 1954, six years elapsed before the FPC was able to terminate the case. 24 F.P.C. 537 (1960). In the final proceeding, the Commission observed that by using individual ratemaking it could complete its current regulatory business in the year 2043, but only if it tripled its staff! Id. at 546.

13. Statement of General Policx No. 61-1, 24 F.P.C. 818 (1960). See McGee, Independent Producers-After Six Years of FPC, im ProceEdINGS of THE AMERICAN Bar Association Section of Mineral and Natural Resources law 219 (1960); Note, FPC Regulation of Independent Producers of Natural Gas, 75 HARv. L. REv. 549 (1962). Area ratemaking has since been promulgated as a rule. 18 C.F.R. $\S 2.66$ (a) (1973).

For a general summary of the background of area rate regulation by the FPC, see Southeru Louisiana Area Rate Cases v. FPC, 428 F.2d 407, 415-18 (5th Cir.), cert. denied, 400 U.S. 950 (1970).

14. The Commission has established eight geographically identifiable areas: (1) Rocky Mountain Area; (2) Texas Gulf Coast Area; (3) Appalachian Area; (4) Illinois Basin Area; (5) Southern Louisiana Area, (which includes the offshore Gulf of Mexico area); (6) Permian Basin Area, (which includes parts of Texas and New Mexico); (7) Other Southwest Area; and (8) Hugoton-Anadarko Area, (encompassing parts of Oklahoma and Kansas). See, e.g., Placid Oil Co. v. FPC, 483 F.2d 880, 886 n.3 (5th Cir.), cert. granted sub nom. Mobil Oil Corp. v. FPC, 42 U.S.L.W. 3405 (U.S. Jan. 15, 1974) (No. 73-437).

Rate proceedings for the Appalachian and rllinois Basin Areas were consolidated in one proceeding. Appalachian and Illinois Basin Area, 44 F.P.C. 1112 (1970).

15. Statement of General Policy, supra note 13, at 820. See, e.g., Area Rate Proceeding, 24 F.P.C. 1121, 1124 (1960).

16. Permian Basin Area Rate Proceeding, 34 F.P.C. 159 (1965), rev'd in part and aff'd in part sub nom., Skelly Oil Co. v. FPC, 375 F.2d 6 (10th Cir. 1967), rev'd 
Area. In 1968, in Permian Basin Area Rate Cases, ${ }^{17}$ the Supreme Court sustained the FPC's authority to regulate producers' interstate sales by the prescription of such maximum area rates, rather than by proceedings conducted on an individual producer basis. However, since the area rates in question in the Permian case had been established pursuant to formal adjudicatory procedures, ${ }^{18}$ the Court did not reach the question of whether such procedures are required in ratemaking by the FPC. Nevertheless, the Court did observe that Congress had entrusted the Commission with broad responsibility for the regulation of the natural gas industry, as well as substantial discretion in its choice of a regulatory method. ${ }^{19}$

Following the Supreme Court's approval in Permian of its area ratemaking procedures, the FPC instituted several similar proceedings. ${ }^{20}$ However, in 1970, noting the length and expense inherent in establishing area rates in the context of formal adjudications, and relying on the broad dicta in Permian, the Commission announced its intention to promulgate rates through an informal rulemaking procedure. $^{21}$

in part and affd in part sub nom., Permian Basin Area Rate Cases, 390 U.S. 747, 755 (1968).

17. 390 U.S. 747 (1968). See Dakin, supra note 4, at 53-58; Kitch, The Permian Basin Area Rate Cases and the Regulatory Determination of Price, 116 U. PA. L. REv. 191 (1967). See generally Breyer \& MacAvoy, The Natural Gas Shortage and the Regulation of Natural Gas Producers, 86 HARv. L. Rev. 941 (1973).

In FPC v. Texaco, Inc., 377 U.S. 33 (1964), the Supreme Court first authorized the FPC to use procedural shortcuts in another aspect of its regulatory process. The Court held that natural gas companies, which had participated in hearings to develop pricing regulations which provided for the summary rejection by the FPC of contracts inconsistent with those regulations, were not denied a statutory hearing when contracts they subsequently submitted were rejected as a per se violation of the regulations without a hearing. Id. at 39. See Fuchs, Agency Development of Policy Through RuleMaking, 59 Nw. U.L. Rev. 781, 782-83 (1965). See generally Davis, The Requirement of Opportunity to be Heard in the Administrative Process, 51 YALE L.J. 1093 (1942); Gellhorn \& Robinson, Summary Judgment in Administrative Adjudication, 84 HARV. L. REV. 612 (1971).

18. See note 16, supra.

19. See note 58 infra and accompanying text. See generally Fuchs, The New Administrative State: Judicial Sanction for Agency Self-Determination in the Regulation of Industry, 69 Colum. L. Rev. 216, 220-21 (1969) (noting that Permian represents a siguificant extra-statutory developnient in the regulatory process).

20. See, e.g., Southern Louisiana Area Rate Proceeding, 40 F.P.C. 530 (1968), aff'd, 428 F.2d 407 (5th Cir.), cert. denied, 400 U.S. 950 (1970); Hugoton-Anadarko Area Rate Proceeding, 44 F.P.C. 761 (1970), aff'd, 466 F.2d 974 (9th Cir. 1972).

21. The first area rate proceeding after Permian in which the FPC did not conduct a full evidentiary hearing was the Appalachian and Illinois Basin Area Proceeding, 86 P.U.R.3d 16 (FPC 1970). The Commission accepted written comments and allowed interested parties to make an oral presentation at a staff conference, at which minutes were taken. Id. at 21-22. In addition, the Commission made a record of all evidence 


\section{Ratemaking as Rulemaking: The Statutory Context}

\section{The Administrative Procedure Act}

Under the Administrative Procedure Act (APA) the term "rule" is defined as including "the approval or prescription" of future rates. ${ }^{22}$ Two forms of rulemaking procedures are provided in the APA. Generally, rulemaking may be conducted pursuant to the informal manner outlined in section 4 of the Act. ${ }^{23}$ These informal procedures require only that the agency publish notice of the proposed rulemaking in the Federal Register and afford interested parties the opportunity to participate "through submission of written data, views, or arguments."24 The agency may in its discretion allow oral presentation; however, if it so decides, it is not limited in its decision to evidence adduced at the hearing, for it may also draw upon its own expertise and outside sources. ${ }^{25}$ Upon adoption, a rule must incorporate a brief statement

it considered. Id. at 21. However, the Conmission determined that there was no need for cross-examination, since the parties had failed to put specific facts in controversy. Id. at 22. No appeal was taken in the case. See Dakin, supra note 4, at 71-73.

22. 5 U.S.C. $\$ 551(4)$ (1970). The American Bar Association has recommended that the APA be amended to eliminate a blanket inclusion of rateinaking as rulemaking. See APA Proposals for Amendments to the Administrative Procedure Act, 24 AD. L. Rev. 371, 389-91 (1972). A rule is generally defined by the APA as "the whole or a part of an agency statement of general or particular applicability and future effect ...."Id. For a detailed discussion of the difference between a rule and an order, see Rutledge, The Distinction Between a Rule and an Order in the Administrative Procedure Act, 6 MraMI L.Q. 359 (1952).

23. 5 U.S.C. $\$ 553$ (1970).

24. Id. $\$ 553(\mathrm{c})$. In California Citizens Band Ass'n v. Umited States, 375 F. $2 \mathrm{~d}$ 43, 50 \& n.11 (9th Cir.), cert. denied, 389 U.S. 844 (1967), the Nimth Circuit held that section 4 of the APA only required that an agency provide opportunity for and consider written comments. The court concluded that additional procedures were only necessary if required by another statute. $1 d$. at 54. See also Virgin Islands Hotel Ass'n v. Virgin Islands Water \& Power Authority, 476 F.2d 1263, 1268-69 (3d Cir.), cert. denied, 94 S. Ct. 576 (1973); Bunny Bear, Inc. v. Peterson, 473 F.2d 1002, 1005 (1st Cir. 1973).

One commentator has pointed out the limitations inherent in this form of "participation" in the rulemaking process:

A person adversely affected in some serious way by a proposed rule unay find hittle solace in the opportunity to submit a written comment. He has no way of knowing whether it will be read by the person with the ultimate power of decision, or indeed, whether it will be read at all. Hamilton, Procedures for the Adoption of Rules of General Applicability: The Need for Procedural Innovation in Administrative Rulemaking, 60 CALIF. L. REv. 1276, 1314 (1972).

25. Since an agency decision based upon informal rulemaking procedures need not be inade "on the record," 5 U.S.C. \& 553(c) (1970), courts construe the lack of "on the record" language to mean that the agency may rely on its own knowledge, as well as on external sources. See Pacific Coast European Conference v. Umited States, 350 F.2d 197, 205 (9th Cir.), cert. denied, 382 U.S. 958 (1965); accord, California Citizens Band Ass'n v. United States, 357 F.2d 43, 54 (9th Cir.), cert. denied, 389 U.S. 
regarding its basis and purpose. ${ }^{26}$ With respect to the second type of rulemaking, the APA provides that "[w] hen rules are required by statute to be made on the record after opportunity for an agency hearing"27 the agency must proceed by the formal procedures described im sections 7 and 8 of the Act. ${ }^{28}$ These sections require adherence to the procedural formalities inherent in an adjudication, ${ }^{29}$ imcluding the right to present oral or documentary evidence, ${ }^{30}$ present rebuttal

844 (1967); cf. American Airlines, Inc. v. CAB, 359 F.2d 624, 629-30 (D.C. Cir.), cert. denied, 385 U.S. 843 (1966).

26. 5 U.S.C. $\S 553$ (c) (1970). But see Hoving Corp. v. FTC, 290 F.2d 803 (2d Cir. 1961) (holding that a rule would not be declared invalid for failure to include within the rule a statement of its basis and purpose if these factors were obvious to the affected parties from the governing legislation and the rulenaking procedure afforded).

27. 5 U.S.C. $\$ 553(\mathrm{c})(1970)$.

28. The provision invoking formal rulemaking is contained in section 4 (c) of the APA, Id.: "When rules are required by statute to be made on the record after opportunity for an agency hearing, sections 556 and 557 of this title [sections 7 and 8 of the Act] apply instead of [informal rulemaking]." Sections 7 and 8 provide for trialtype proceedings, presided over by one or more hearing officers. Parties to formal ruleniaking have full opportunity to present evidence and conduct cross-examination. At the conclusion of the proceeding, the hearing officer makes a "recommended" decision to the agency. The agency may then promulgate a rule based upon the transcript of the testimony, exhibits, and other filings, which constitutes the exclusive record for its decision. See note 29 infra.

Formal rulemaking is an exception to the more generally applicable informal rulemaking procedures. See United States v. Florida East Coast Ry., 410 U.S. 224 (1973); United States v. Allegheny-Ludlum Steel Corp., 406 U.S. 742 (1972); and text accompanying notes 61-73 infra. The scheme of section 553(c) contemplates that agencies may proceed by inforinal rulemaking, unless required by another statute to conduct formal rulemaking. Cf. Automotive Parts \& Accessories Ass'n v. Boyd, 407 F.2d 330, 334-35 (D.C. Cir. 1968). For examples of statutes that contain the "on the record" phrasing and which therefore require formal rulemaking, see Walsh-Healy Act, 41 U.S.C. $\$ 43 \mathrm{a}$ (b) (1970); Drug Abuse Prevention and Control Act, 21 U.S.C. $\$ 811(\mathrm{a})$ (1970).

29. The APA also requires adjudications "required by statute to be determined on the record after opportunity for an agency hearing," 15 U.S.C. \& 554(a) (1970), to be conducted pursuant to the more elaborate procedures specified in sections 7 and 8 . Under the APA formal ruleniaking procedures differ somewhat from those prescribed for formal adjudications. In formal rulemaking all or part of the evidence may be taken in the form of written submissions rather than oral testimony, "when a party will not be prejudiced thereby." Id. \$ 556(d). See note 124 infra. Further, the agency's presiding employee is not always required to recommend a decision. Id. $\S 557$ (b). Moreover, the procedures required by section 5 apply only to adjudications. Id. \& 554 . The APA provides no standards to be used in "informal" administrative adjudications. However, the due process clause has been held to require certain procedural safeguards in cases of administrative adjudication. See, e.g., Perry v. Sindermann, 408 U.S. 593 (1972); Goldberg v. Kelly, 397 U.S. 254 (1970); Wong Yang Sung v. McGrath, 339 U.S. 33 (1950); Ohio Bell Tel. Co. v. Public Util. Comm'n, 301 U.S. 292 (1937); Dixon v. Alabama State Bd. of Educ., 294 F.2d 150 (5th Cir.), cert. denied, 368 U.S. 930 (1961); Citizens Nat'1 Bank v. Camp, 317 F. Supp. 1389 (D. Md. 1970).

30. 5 U.S.C. $\$ 556(d)(1970)$. 
evidence, ${ }^{31}$ and conduct cross-examination. ${ }^{32}$ In adopting a final rule under sections 7 and 8, the agency must base its decision only upon evidence compiled in the formal record of the adjudication, ${ }^{33}$ and the record inust include not only the rule adopted but also all agency findings and conclusions on material issues of fact and law, as well as its reasoning for each. ${ }^{34}$

\section{The Natural Gas Act}

The Natural Gas Act does not specifically provide that rates be established by a proceeding "on the record." 35 Section 5 of the Act

31. Id.

32. Id. See 2 K. Davis $\S 14.05$.

33. 5 U.S.C. $\$ 556(d)(1970)$. The agency's decision based upon the record must be supported by "substantial evideuce." Id. The Supreme Court has defined substantial evidence as "more than a mere scintilla. It means such relevant evidence as a reasonable mind might accept as adequate to support a conclusion." Consolidated Edison Co. v. NLRB, 305 U.S. 197, 229 (1938); accord, John W. McGrath Corp. v. Hughes, 264 F.2d 314, 316 (2d Cir.), cert. denied, 360 U.S. 931 (1959). In NLRB v. Columbian Enameling \& Stamping Co., 306 U.S. 292 (1939), the Supreme Court held that evidence in support of an agency decision subject to the "substantial evidence" test must be sufficient "to justify, if the trial were to a jury, a refusal to direct a verdict when the conclusion sought to be drawn from it is one of fact for the jury." Id. at 300; accord, Consolo v. Federal Maritime Comm'n, 383 U.S. 607, 619-21 (1966); see $4 \mathrm{~K}$. Davis $\$ 29.02$; McCoRMICK on EVIDENCE $\$ 352$ (E. Cleary ed. 1972). In applying this test, the reviewing court must examine the whole record and not merely evidence tending to support the agency's findings. Universal Camera Corp. v. NLRB, 340 U.S. 474, 477 (1951). See Mobil Oil Corp. v. FPC, 483 F.2d 1238, 1258 (D.C. Cir. 1973; cf. Texaco, Inc. v. FPC, 329 F.2d 223, 227 (D.C. Cir.), cert. denied, 375 U.S. 941 (1963) (holding that, under the NGA, the reviewing court must sustain the FPC's finding of fact if supported by substantial evidence, but that the findings could not be sustained in the face of an assertion that the Commission had excluded material evidence not otherwise entered in the record).

34. 5 U.S.C. $\& 557$ (c) (1970). The legislative history of the APA indicates that Congress intended that agencies incorporate in the record all findings and conclusions in order to preclude controversy on whether and how the agency resolved each issue. S. Doc. No. 248, 79th Cong., 2d Sess. 288 n.19-20 (1946). See NLRB v. ClementBlythe Cos., 415 F.2d 78, 81 (4th Cir. 1969) (court refusal to enforce an order of the NLRB for failure to coinply with section 557(c)). See also Anglo-Canadian Shipping Co. v. Federal Maritime Comm'n, 310 F.2d 606, 617 (9th Cir. 1962).

35. Although the NGA does not expressly provide for ruleinaking "on the record," it was widely assumed at the time of the enactment of the APA that the NGA required formal ruleinaking. The Department of Justice, in an instructional manual prepared after the enactment of the APA, stated:

Statutes authorizing agencies to prescribe future rates (i.e., rules of either general or particular apphicability) for public utilities and common carriers typically require that such rates be established only after an opportunity for a hearing before the agency. Such statutes rarely specify in terns that the agency action must be taken on the basis of the "record" developed in the hearing. However, where rates or prices are established by an agency after a hearing required by statute, the agencies theinselves and the courts have long assumed that the agency's action must be based upon the evidence ad- 
authorizes the Commission to fix just and reasonable rates, and provides that it may set aside any rates determined "after a hearing" to be "unjust, unreasonable, unduly discriminatory, or preferential."36 General procedural guidelines for such hearings are found in section 15 of the Act, which provides in part:

All hearings, investigations, and proceedings .... shall be governed by rules of practice and procedure to be adopted by the Commission, and in the conduct thereof the technical rules of evidence need not be applied. No informality in any hearing, investigation, or proceeding or in the manner of taking testimony shall invalidate any order, decision, rule, or regulation . . . .37

Section 16 empowers the Commission "to perform any and all acts, and to prescribe . . . such orders, rules and regulations as it may find necessary and proper to carry out the provisions of this [Act]."38 Thus, the Act suggests that the FPC is allowed to allow some flexibility in determining specific procedural aspects of ratemaking hearings. Yet, the NGA further requires that the Commission's factual findings be supported by "substantial evidence" in order to be conclusive in a judicial proceeding, ${ }^{39}$ and therefore, it is questionable whether such flexibility extends so far as to permit rates to be established by the informal rulemaking procedures of the APA under which no formal evidentiary record is developed. ${ }^{40}$

\section{Hearing Requtrements in Ratemaking Proceedings- Judictal PRECEDENT}

Prior to the decisions in Phillips and Mobil no court had squarely

duced at the hearing. Sometimes the requirement of decision on the record is readily inferred from other statutory provisions defining judicial review. For example, rate orders issued by the Federal Power Commission pursuant to the Natural Gas Act (15 U.S.C. \& 717) may be made only after hearing; upon review in a circuit court of appeals or the Court of Appeals for the District of Columbia, the Commission certifies and files with the court "a transcript of the record upon which the order complained of was entered" and the Commission's findings of fact "if supported by substantial evidence, shall be conclusive." It seems clear that these provisions of the Natural Gas Act must be construed as requiring the Commission to determine rates "on the record after opportunity for an agency hearing." ATTORNEY GENERAL's MANUAL ON THE ADMINISTRATIVE PROCEDURe ACT 33 (1947).

See also Ginnane, "Rule Making," "Adjudication" and Exemptions Under the Administrative Procedure Act, 95 U. PA. L. REv. 621, 629 n.17 (1947).

36. 15 U.S.C. $\$ 717 d(1970)$. The Commission may decrease rates found to be "unlawful" or "not the lowest reasonable rates," but it may not increase any rate unless in accordance with a new rate schedule filed by the natural gas company. Id. $\$ 717 \mathrm{~d}$ (a).

37. $I d . \S 717 \mathrm{n}$.

38. Id. $\S 7170$.

39. Id. $\$ 717 \mathrm{r}(\mathrm{b})$. See note 33 supra.

40. Compare notes 94,95 infra and accompanying text. 
addressed the question of whether the FPC must establish rates in the context of formal rulemaking proceedings. ${ }^{41}$

\section{Pre-APA Ratemaking Decisions}

In two related cases decided prior to the enactment of the APA, Morgan v. United States ${ }^{42}$ (Morgan I) and Morgan v. United States ${ }^{43}$ (Morgan II), the Supreme Court considered the validity of procedures employed by the Secretary of Agriculture in establishing rates under the Packers and Stockyards Act of 1921.44 In Morgan I, plaintiffs alleged that the Secretary had not complied with the statutory requirement that rates be set pursuant to a "full hearing." the meaning of that term, Chief Justice Hughes indicated that the nature of the hearing required under a particular statute depends upon the nature of the determination to be made. ${ }^{46}$ Although lie observed that ratemaking is "legislative" in some respects, the Chief Justice stated that

[a] proceeding of this sort requiring the taking and weighing of evidence, determinations of fact based upon the consideration of the evidence, and the making of an order supported by such findings, has

41. See text accompanying notes 18-21 supra.

42. 298 U.S. 468 (1936). In an earlier case, ICC v. Louisville \& Nashville R.R., 227 U.S. 88 (1913), the Supreme Court stated that ratemaking pursuant to the Hepburn Act of 1906 , cl. 3591 , § 15, 34 Stat. 584, which gave the ICC authority to set certain railroad class and commodity rates, was "quasi-jndicial in claracter." 227 U.S. at 91. The Court construed the "Iearing" requirement contained in that statute as calling for a full evidentiary learing, because the rights of the parties depended upon questions of fact which required an adversary proceeding. Specifically, the Court stated that

there is no hearing when the party does not know what evidence is offered or considered and is not given the opportunity to test, explain, or refute .... All parties must be fully apprised of the evidence submitted or to be considered, and must be given opportunity to cross-examine witnesses, to inspect documents and to offer evidence in explanation or rebuttal. Id. at 93.

See also Ohio Bell Tel. Co. v. Public Util. Comm'n, 301 U.S. 292 (1937), where the Court found a denial of due process when rates previously collected were ordered to be refunded on the basis of undisclosed evidence which was never made part of the record before the agency.

43. 304 U.S. 1 (1938).

44. 7 U.S.C. $\$ 181$ et seq. (1970).

45. 298 U.S. at 473. Under the requirements of Packers and Stockyards Act, if the Secretary of Agriculture, after complaint or upon his own initiative, decides to examine a rate charged by a stockyard owner or market agency in connection with the furnishing for stockyard services to determine whether it is just and reasonable, he inust conduct a "full learing." 7 U.S.C. $\$ 211$ (1970). Upon finding that a rate is "unjust, unreasonable, or discriminatory," the Secretary may determine and prescribe what a just and reasonable rate will be. Id. \$ 211(a).

46. 298 U.S. at $479-80$. 
a quality resembling that of a judicial proceeding. Hence it is frequently described as a proceeding of a quasi-judicial character. ${ }^{47}$

In Morgan II, a later case in the same litigation, ${ }^{48}$ the Court again considered the meaning of the statutory requirement of a "full liearing." In rejecting the district court's conclusion on remand that the full hearing requirennent was satisfied by allowing interested parties merely to present written comments, the Court reasoned that

[t] he right to a hearing embraces not only the right to present evidence but also a reasonable opportunity to know the claims of the opposing party and to meet thein. The right to submit argument implies that opportunity; otherwise the right may be but a barren one. ${ }^{49}$

Relying on this reasoning, the Court then found that the Secretary had accepted the findings of the government staff without allowing the regulated parties any reasonable opportunity to be apprised of those findings and to contest them. It therefore concluded that the ratennaking procedures were "fatally defective." In sum, the Morgan decisions tend to indicate that where a statute provides that rates are to be made pursuant to a hearing, such provision requires that the regulated party be given an opportunity for oral argument and crossexamination. ${ }^{51}$

47. Id. at 480 (emphasis in original). The plaintiffs in Morgan $I$ had alleged that a "full hearing" had not been given since the Secretary, who issued the rate order, had neither heard nor considered the evidence submitted, relying instead solely upon consultations with einployees in the Department of Agriculture for information regarding the rate proceeding. Id. at 476 . Finding that such allegations, if proved, would represent conduct contravening the statutory requirement for a hearing, the Supreme Court held that the district court had erred in striking these allegations. Id. at 481 . The Court remanded the case to the district court for a determination of whether, in light of the Supreine Court's opiniou, the plaintiffs had been afforded a proper hearing. Id. at 482 .

48. Following the remand by the Supreme Court in Morgan I, the district court held that the procedures followed by the Secretary in the case had indeed afforded the plaintiffs a proper hearing and therefore the court affirmed the challenged order. Morgan v. United States, 23 F. Supp. 380 (W.D. Mo. 1937). In Morgan II, 304 U.S. 1 (1938), the plaintiffs challeuged this finding by the district court.

49. 304 U.S. at 18.

50. Id. at 22. Having determined that the hearing was defective, the Court declared the order invalid and reversed the district court without reaching the merits of the rates established by the Secretary. $I d$.

51. However, the Morgan cases were decided prior to the enactment of the APA in 1946. The APA specifically provides that ratemaking is a rulemaking procedure, 5 U.S.C. $\$ 551(4)$ (1970), and requires formal procedures only where the statute requires rules to be made "on the record." See notes $22,27,28$ supra and accompanying text. Accordingly, to the extent that the Morgan cases' observations regarding what constitutes an adequate hearing rest upon the Court's opinion that such proceedings are essentially quasi-judicial in nature, see text accompanying note 47 supra, the enactment of the APA undercuts that rationale. On the other hand, the Department 


\section{The Supreme Court and FPC Ratemaking Procedures}

In FPC v. Natural Gas Pipeline Co. ${ }^{62}$ the Supreme Court, in its initial consideration of the Natural Gas Act, ${ }^{53}$ discussed the ratemaking function of the Commission under section 5 of the Act and noted that an FPC rate order must be "preceded by a hearing and findings." In accordance with the then prevailing FPC practice, a formal hearing had been provided. ${ }^{55}$ While the Court did not hold that a formal adjudicative proceeding was required by the NGA, its conclusion that the proceeding had constituted a fair hearing implicitly approved the use

of Justice, in its Manual on the APA, has stated that provisions of the Packers and Stockyards Act and the Interstate Commerce Act, both of which predated the APA, should be interpreted as requiring the respective agencies to determine rates "on the record after opportunity for agency heariug" notwithstanding the absence of those precise words in the respective statutes. The Manual states:

The Interstate Commerce Commission and the Secretary of Agriculture nuay, after hearing, prescribe rates for carriers and stockyard agencies, respectively. Both types of rate orders are reviewable under the Urgent Deficiencies Act of 1913 [ch. 32, 38 Stat. 219, 220 (1913), as amended, 28 U.S.C. $\$ 2328(1970)$. The amended Act provides that suits to suspend or set aside orders nuade pursuant to the Interstate Commerce Act or the Packers and Stockyards Act must be brought before a three-judge district court]. Nothing in the Interstate Commerce Act, the Packers and Stockyards Act, or the Urgent Deficiencies Act requires in terms that such rate orders be "made on the record," or provides for the filing of a transcript of the adnuinistrative record with the reviewing court, or defines the scope of judicial review. However, both of these agencies and the courts have long assumed that such rate orders must be based upon the record made in the hearing; furthermore, it has long been the practice under the Urgent Deficiencies Act to review such orders on the basis of the administrative record which is submitted to the reviewing court. It appears, therefore, that rules (as defined in section $2(\mathrm{c})$ ) which are issued after a hearing required by statute, and which are reviewable under the Urgent Deficiencies Act on the basis of the evidence adduced at the agency hearing, must be regarded as "required by statute to be inade on the record after opportunity for an agency hearing."

With respect to the types of rule making discussed above, the statutes not only specifically require the agencies to hold hearings but also, specifically, or by clear implication, or by estabhished administrative and judicial construction, require such rules to be formulated upon the basis of the evidentiary record made in the hearing. In these situations, the public rule nuaking procedures required by section $4(\mathrm{~b})$ will consist of a hearing conducted in accordance with sections 7 and 8. ATTORNEY GENERAL'S MANUAL ON THE ADMINISTRATIVE PROCEDURE ACT 33-34 (1947) (citations omitted). 35 supra.

For a similar view of the hearing requirement contained in the NGA see note

52. 315 U.S. 575 (1942).

53. In an opimion by Chief Justice Stone, the Suprente Court primcipally held that the rate provisions of the NGA were consistent with the due process clause of the fifth amendment, and were within the commerce power. The Court stated that the "authority of Congress to regulate the prices of commodities in interstate commerce is at least as great under the Fifth Amendment as is that of the states under the Fourteenth to regulate the prices of commodities in intrastate commerce." Id. at 582.

54. Id. at 583 .

55. The gas company was allowed to present all its evidence on direct aud rebuttal examination. It had full opportunity to cross-examine each witness offered by the FPC and the Illinois Commerce Commission. Id. at 584. 
of such formal procedures in ratemaking under that Act.

Several cases which have examined other aspects of FPC procedure have suggested a judicial willingness to allow the Commission substantial flexibility in carrying out its statutory responsibilities. ${ }^{56}$ This attitude was particularly evident in the Supreme Court's opinion in the Permian Basin Area Rate Cases. ${ }^{57}$ In sustaining the FPC's authority to set rates on an area-wide basis, the Permian Court emphasized the need to permit the Commission to formulate procedures designed to effect a more expeditious and effective systein of regulation. The Court observed that it had

repeatedly held that the width of administrative authority must be measured in part by the purposes for which it was conferred.

...

... [T] he history of producer regulation has confirmed, that the ultimate achievement of the Commission's regulatory purposes may easily depend upon the contrivance of more expeditious administrative methods. The Commission believes that the elements of such methods may be found in area proceedings. "[C]onsiderations of feasibility and practicability are certainly germane" to the issues before us . . . . We cannot, in these circumstances, conclude that Congress has given au-

56. See FPC v. Texaco, Inc., 377 U.S. 33 (1964), discussed in note 17 supra; accord, Mobil Oil Corp. v. FPC, 469 F.2d 130, 139 (D.C. Cir. 1972).

In FPC v. Louisiana Power \& Light Co., 406 U.S. 621 (1972), the Supreme Court stated that section 16 of the NGA, 15 U.S.C. $\$ 717 o$ (1970), demanded a generous construction in order for the FPC to meet its broad responsibilities, 406 U.S. at 642, and held that section 16 gave the FPC "the necessary degree of flexibility" to carry out its mandate. Id. Similarly, in Amerada Petroleum Corp. v. FPC, 293 F.2d 572 (10th Cir. 1961), cert. denied, 368 U.S. 976 (1962), the Tenth Circuit held that section 16 was "a sweeping grant of administrative authority to be exercised in the sound discretion of the Commission." 293 F.2d at 575. See also FPC v. East Ohio Gas Co., 338 U.S. 464, 474 n.15 (1950).

In Niagara Mohawk Power Corp. v. FPC, 359 F.2d 153, 157 (D.C. Cir. 1967), the District of Colunnbia Circuit held that the Commission had authority to assign au effective date for a license prior to its date of issuance. The court stated that the Commission's authority to do so

while not expressly set forth in the [Federal Power Act, 16 U.S.C. $\$ 791 \mathrm{a}$ et seq. (1970) 1 is fairly implied, assuming reasonable exercise of the authority. The Act is not to be given a tight reading wherein every action of the commission is justified only if referable to express statutory authorization. On the contrary, the Act is one that entrusts a broad subject matter to administration by the Commission, subject to Congressional oversight, in the light of new and evolving probleins and doctrines. Id. at 158.

The same court, in construing the NGA in a later case reaffirmed this broad view of the FPC's authority by holding that "the Commission has broad discretion to seek a given objective either through ad hoc adjudicatory proceedings or rulemaking." City of Chicago v. FPC, 458 F.2d 731, 742 (D.C. Cir. 1971), cert. denied, 405 U.S. 1074 (1972); accord, Alabama-Tennessee Natural Gas Co. v. FPC, 359 F.2d 318, 343 (5th Cir.), cert. denied, 385 U.S. 847 (1966).

57. See notes 17-21 supra and accompanying text. 
thority inadequate to achieve with reasonable effectiveness the purposes for which it has acted. ${ }^{68}$

However, notwithstanding this broad language concerning the FPC's need for procedural flexibility, Permian only dealt with the authority of the Commission to estabhish rates on area rather than individual bases. As noted above, the Permian rates were proinulgated through the use of formal adjudicatory procedures. ${ }^{58}$ Thus, the issue of whether the FPC could establish area rates by informal as opposed to formal procedures was not confronted.

The Supreme Court Considers Formal Rulemaking-Allegheny-Ludlum and Florida East Coast Railway

As noted earlier the NGA provides that the FPC is to establish rates "after a hearing" and that the factual predicates for such rates must be supported by substantial evidence. ${ }^{60}$ Recently, the Supreme Court has examined the question of what language in an administrative agency's enabling statute will imvoke the formal rulemaking procedures prescribed in sections 7 and 8 of the APA. In United States v. Allegheny-Ludlum Steel Corp., ${ }^{01}$ the Court upheld freight car service rules adopted by the Interstate Commerce Commission pursuant to informal rulemaking procedures under section 4 of the APA. ${ }^{62}$ After characterizing the proceedings as ruleinaking-that is, as an exercise of legislative rather than adjudicatory power by the ICC-Justice Rehnquist, speaking for an unanimous Court, rejected the contention that the rulemaking proceeding was defective because it failed to comply with sections 7 and 8 of the APA. ${ }^{63}$ Recognizing that those

58. 390 U.S. at 776-77. The Supreme Court in Permian further observed that "administrative authorities must be permitted, consistently with the obligations of due process, to adapt their rules and policies to the demands of changing circumstances." Id. at 784 .

Recently, the Fifth Circuit observed that "the thrust of Permian is that the FPC is free to make an administrative determination which it believes will foster the most efficient and thorough regulation of natural gas rates." Placid Oil Co. v. FPC, 483 F.2d 880, 912 (5th Cir. 1973), cert. granted sub nom., Mobil Oil Corp. v. FPC, 42 U.S.L.W. 3405 (U.S. Jan. 15, 1974) (No. 73-437). Similarly broad language may be found in City of Chicago v. FPC, 458 F.2d 731 (D.C. Cir. 1971), cert. denied, 405 U.S. 829 (1972). In that case, the court stated that the "ability to choose with relative freedom the procedure it will use to acquire relevant information gives the Commission power to realistically tailor the proceedings to fit the issues before it . . . ." Id. at 744. See note 56 supra.

59. See note 18 supra and accompanying text.

60. See notes 36,39 supra and accompanying text.

61. 406 U.S. 742 (1972).

62. For a discussion of freight car service rules, see note 68 infra.

63. 406 U.S. at 756-57. As noted earlier, see note 29 supra, it has been 
sections applied to rul'emaking proceedings only when the statute in question requires rules "to be made on the record after opportunity for an agency liearing,"64 the Court observed that section 1(14)(a) of the Interstate Commerce Act merely required that rules be made "after a hearing."65 The Court added:

We do not suggest that only the precise words "on the record" in the applicable statute will suffice to make sections [7] and [8] applicable to rulemaking proceedings, but we do liold that the language of . . . [section 1(14)(a)] is insufficient to invoke these sections. ${ }^{66}$

In United States v. Florida East Coast Railway, ${ }^{67}$ the Court upheld the ICC's use of informal rulemaking procedures in setting incentive per diem charges for the use of one railroad of freight cars owned by another. ${ }^{68}$ The district court had held that the "after a hearing"

held that due process requires that administrative adjudications be conducted pursuant to minimum procedural safeguards. However, courts have consistently held that where rulemaking is concerned, due process does not require any procedural standards beyond the notice-and-comment procedures set forth in section 4 of the APA. See, e.g., Weinberger v. Hynson, Westcott \& Dunning, Inc., 412 U.S. 609, 625 (1973); Anaconda Co. v. Ruckelshaus, 482 F.2d 1301, 1306-07 (10th Cir. 1973); Duquesne Light Co. v. EPA, 481 F.2d 1, 8-10 (3d Cir. 1973); Virgin Islands Hotel Ass'n v. Virgin Islands Water \& Power Authority, 476 F.2d 1263, 1268 (3d Cir.), cert. denied, 94 S. Ct. 576 (1973); California Citizens Band Ass'n v. United States, 375 F.2d 43, 50 (9th Cir.), cert. denied, 389 U.S. 844 (1967); Superior Oil Co. v. FPC, 322 F.2d 601, 609 (9th Cir. 1963), cert. denied, 377 U.S. 922 (1964); Air Lime Pilots Ass'n Int'l v. Quesada, 276 F.2d 892, 896 (2d Cir. 1960); cf. Bi-Metallic Inv. Co. v. State Bd. of Equalization, 239 U.S. 441 (1915). Consequently, the Court's distinction between legislative and adjudicative functions suggests that due process considerations may prompt invocation of the trial-type procedures prescribed by sections 7 and 8 of the APA, notwithstanding an absence of the specific words "on the record" in the agency's enabling statute.

64. 5 U.S.C. $\& 553(c)(1970)$, cited in 406 U.S. at 757. See Joseph E. Seagram \& Sons, Inc. v. Dillon, 344 F.2d 497 (D.C. Cir. 1965) (per curiam) (holding that formal rulemaking was not required for the disapproval of a label, since the governing statute did not require rules to be "made on the record" after opportunity for an agency hearing); Pacific Coast European Conference v. United States, 350 F.2d 197, 205 (9th Cir.), cert. denied, 382 U.S. 958 (1965). See also Siegel v. AEC, 400 F.2d 778 (D.C. Cir. 1968); Air Line Pilots Ass'n, Int'l v. CAB, 215 F.2d 122 (2d Cir. 1954).

65. 49 U.S.C. $\$ 1(14)$ (a) (Supp. 1973). See generally R. Fellmuth, The INTERstate COMmerce Commssion (1970); Note, The Freight Car Shortage and ICC Regulation, 85 HARv. L. Rev. 1583 (1972).

66. 406 U.S. at 757.

67. 410 U.S. 224 (1973).

68. The agency action under challenge in Allegheny-Ludlum was merely a set of rules requiring that freight cars, after being unloaded, be returncd in the direction of the lines of the railroad which owned the cars. United States v. Allegheny-Ludlum Steel Corp., 406 U.S. 742, 742-43 (1972). In contrast, the rule in question in Florida East Coast $R y$., inposed specific per diem rates to be charged in every case for the use by one railroad of freight cars owned by another. Umited States v. Florida East Coast Ry., 410 U.S. 224, 233 (1973). These per diem charges were desigued to en- 
language in section 1(14)(a) of the Interstate Commerce Act required that formal "on the record" rulemaking be conducted in accordance with sections 7 and 8 of the APA. ${ }^{90}$ In reversing the district court's decision, the Supreme Court noted that the lower court's conclusion was inconsistent with the Allegheny-Ludlum decision and then elaborated its rationale for holding that a statutory requirement of a "hearing" without more is insufficient to require formal adjudicatory procedures. ${ }^{70}$ Examining relevant provisions of the APA, the Court, again per Justice Rehnquist, concluded that 'the term 'hearing' as used therein does not necessarily embrace either the right to present evidence orally and to cross-examine opposing wituesses, or the right to present oral argument to the agency's decisionmaker."71 Hence, the

courage prompt return of railroad cars, and, unlike the rules in Allegheny-Ludlum imposed unavoidable financial liability upon freight car users. This distinction formed the basis of Justice Douglas' dissent. See note 73 infra.

69. Florida East Coast Ry. v. United States, 322 F. Supp. 725, 728 (M.D. Fla. 1971). A similar conclusion was reached in Long Island Ry. v. United States, 318 F. Supp. 490 (E.D.N.Y. 1970), a case which also involved a clallenge to the validity of procedures employed in the promulgation of a per diem railroad car service rate by the ICC. Writing for a three-judge district court, Judge Friendly concluded in Long Island $R y$. that the ICC was required to promulgate such rates pursuant to formal rulemaking procedures. Judge Friendly conceded that the APA only requires formal evidentiary procedures where rules are "required by the statute to be made on the record after opportunity for agency hearing." Id. at 495, quoting 5 U.S.C. $\$ 553($ c) (1970). See note 28 supra and accompanymg text. However, le felt that "it is rather hard to behieve that the last sentence of $\S 553$ (c) [the formal rulemaking provisions] was directed only to the few legislative sports [sic] where the words 'on the record' or their equivalent had found their way into the statute book." 318 F. Supp. at 496.

Examining the "hearing" requirement of section 1(14)(a) of the Interstate Commerce Act, Judge Friendly reasoned that when Congress origmally enacted that section in 1917, its frame of reference for the term hearing was a then recent Supreme Court decision in ICC v. Louisville \& Nashville R.R., 227 U.S. 88 (1913). As lias been previously noted, the Supreme Court determined in that case that the hearing requirement of the Hepburn Act of 1906, ch. 3581, § 15, 34 Stat. 584, required that the ICC set rates based on an evidentiary hearing. See note 42 supra.

Having concluded that the Interstate Commerce Act required formal rulemaking, Judge Friendly nevertheless concluded that the ICC could dispense with an oral liearing and cross-examination. Relying upon section 7(d) of the APA, 5 U.S.C. $\$ 556$ (d) (1970), which provides that "[i]n rule making ... an agency may, when a party will not be prejudiced thereby, adopt procedures for the submission of all or part of the evidence in written form," he determined that adversary procedures were unnecessary since the parties had failed to put any specific facts in issue. 318 F. Supp. 49899. See Note, Modification of Procedural Formality in Agency Rule-Making Determinations: Long Island v. United States, 46 IND. L.J. 506 (1971).

70. 410 U.S. at 237-38.

71. Id. at 240. Noting that the Interstate Commerce Act was amended in May, 1966 and thus post-dated the 1946 enactment of the APA, the Court concluded that the tern "liearing" as used in the Interstate Commerce Act must be interpreted in light of the informal rulemaking provision of section 4 of the APA, 5 U.S.C. \& 553 
Court reasoned that statutes which require a "hearing" prior to rulemaking may in some circumstances be satisfied by procedures which only comply with the informal "notice and comment" rulemaking procedures outlined in section 4 of the APA. Again the Court stressed that "other statutory language having the same meaning" as the words "on the record hearing" could invoke formal rulemaking requirements; ${ }^{72}$ nevertheless, Justice Rehnquist's analysis left no doubt that the mere requirement of a hearing was insufficient to do so. ${ }^{73}$

\section{VALIDATION OF INFORMAL RATEMAKING-}

\section{Phillips Petroleum Co. v. FPC}

In Phillips Petroleum Co. v. FPC, ${ }^{74}$ the Tenth Circuit, with one judge dissenting, held that the FPC may fix area rates for producers of natural gas pursuant to informal rulemaking procedures. In Phillips the FPC had issued notice of proposed rulemaking procedures for the Rocky Mountain area. ${ }^{75}$ The notice made clear that the ratemaking procedure to be employed would consist of an informal hearing not conducted on the record, which would afford no opportunity for crossexamination. ${ }^{76}$ Under this procedure, the affected producers were to

(1970), which provides that the agency may limit the opportunity for a hearing to the submission of written comments. See note 24 supra and accompanying text.

72. 410 U.S. at 238.

73. However, Justices Douglas and Stewart, who had joined the Court's unanimous opinion in Allegheny-Ludlum, dissented, contending that the majority's opinion violated "traditional concepts of procedural due process." Id. at 246 (dissenting opinion). Justice Douglas, writing for the dissent, argued that "[t]he 'hearing' requirement of $\S 1(14)$ (a) cannot be given a fixed and immutable meaning to be applied in each and every case without regard to the nature of the proceedings." Id. at 251. Justice Douglas distinguished the rules in question from those involved in Allegheny-Ludlum by noting that the per diem incentive rates in Florida East Coast Ry. imposed "a new financial liability." Id. at 252 . See note 68 supra. Thus, he concluded that the Florida East Coast Ry. rate orders were adjudicatory in nature and therefore required fornal evidentiary hearings. Citing ICC v. Louisville \& Nashville R.R., 227 U.S. 88 (1913) and Morgan v. United States, 304 U.S. 1 (1938), see notes 42, 47-51 supra and accompanying text, Justice Douglas concluded that "where, as here, ratemaking must be based on evidential facts, $\$ 1$ (14)(a) requires that full hearing which due process normally entails." 410 U.S. at 253-54; cf. Clagett, Informal Action-Adjudication-Rulemaking: Some Recent Developments in Federal Administrative Law, 1971 DUKE L.J. 51, 78.

Implicit in Justice Douglas' dissent is the argument that, uotwithstanding the fact that the APA specifically defines ratemaking as a rulemaking function rather than an adjudication, see note 51 supra and accompanying text, all ratemaking proceedings which rest upon factual determinations should be conducted pursuant to formal evidentiary procedures. 1974).

74. 475 F.2d 842 (10th Cir. 1973), cert. denied, 42 U.S.L.W. 3401 (U.S. Jan. 14,

75. 36 Fed. Reg. 13,621 (1971).

76. Id. at 13,622 . 
submit written comments and data which the Commission staff would assimilate and reconcile. ${ }^{77}$ Phillips, together with other affected natural gas producers challenged the proposed procedure, contending that the Coinmission was required under the NGA and APA to establish rates in the context of formal adjudicatory hearings. The Counmission rejected these challenges, and the producers sought review in the court of appeals. ${ }^{78}$ After an examination of sections 15 and 16 of the NGA, ${ }^{79}$ the court concluded that those sections granted wide discretion to the FPC in determining the form of its proceedings. ${ }^{80}$ In support of this interpretation the court pointed to the expansive language of the Permian decision and reasoned that the Commission's atteinpt to utilize the more streamlined procedures of informal rulemaking was "to a large degree, the result of the encouragennent which the Supreme Court gave to the FPC to innovate."81 Moreover, the court determined that a record consisting of written comments and data supplied by the producers and compiled by the Commission staff would be a record sufficient for the purpose of effective judicial review. ${ }^{82}$ Finally, the court rejected the contention that the APA required that the FPC proceed by formal rulemaking, observing that

77. Id.

78. 475 F.2d at 856.

79. The court found that the "plain language" of section 15,15 U.S.C. $\& 717 \mathrm{n}$ (1970), authorizes the FPC to adopt a rule providing an informal ratemaking hearing. 475 F.2d at 848 . Moreover, the court noted that section 16, 15 U.S.C. $\$ 7170$ (1970), empowers the Commission "to perform any ... acts ... as it may find necessary and appropriate," and to "prescribe the form or forms of all statements, declarations, applications and reports to be filed." 475 F.2d at 848 .

80. As support for this proposition tbe court cited City of Chicago v. FPC, 458 F.2d 731, 744 (D.C. Cir. 1971), cert. denied, 405 U.S. 1074 (1972). But see Mobil Oil Corp. v. FPC, 483 F.2d 1238, 1262 n.89 (D.C. Cir. 1973).

81. 475 F.2d at 850 . See note 58 supra and accompanying text.

82. Id. In rejecting the petitioners' contention that no record would be created by the informal procedures adopted by the Commission, the majority stated its opinion that

a record resulting from a formal evidentiary hearing [is not necessary]. The important point is that there shall be a record which will allow an orderly review of the Commission's findings and conclusions. Under the rule the record will consist of the writteu comments ... by producer and pipeline companies and composited [sic] by the Commission staff. Id.

But compare note 33 supra and note 95 infra.

Judge Seth, dissenting as to the adequacy of the record allowed by the majority, observed that

[i]t is also apparent that those ordered to be made parties will have no part in the making of the record of the proceedings, that is, through the introduction of exhibits or testimony with the right to object to or test the validity of the material. There is thus assembled material which cannot be considered a "public record," and which is not really identifiable as having been assembled during the course of public proceedings. Id. at 855 (emphasis in original). 
the NGA did not contain the language "on the record." In sum, the majority concluded that ratemaking by informal rulemaking was supported by dicta in the Permian decision and was consistent with both the NGA and APA, and the fact that the FPC previously had estabhished rates in the context of adjudicatory hearings did not preclude it from adopting the more expeditious procedures afforded by informal rulemaking. ${ }^{84}$

\section{THE HYBRID APPROACH TO RATEMAKING-}

\section{Mobil Oil Corp. v. FPC}

In contrast to the Tenth Circuits holding in Phillips, the Court of Appeals for the District of Columbia Circuit in Mobil Oil Corp. v. $F P C^{85}$ held that the FPC could not set transportation rates for interstate pipeline companies pursuant to informal rulemaking procedures. However, the Mobil court did not require the Commission to strictly

83. The court observed that the lack of the words "on the record" in the NGA strongly snpported the contention that "informal rulemaking satisfies the requirements of the APA." Id. at 851. However, the court conceded that "the presence or absence of these are not conclusive," $i d$., and stated that a "more reliable test" is to examine the congressional intent embodied in the particular agency statute. Id. Additionally, the court ignored the logical implication of its own conclusion and, unlike the Mobil court, see notes 85-90, 94-96, 110 infra and accompanying text, failed to consider the significance of the NGA's requirement that FPC determinations be supported by substantial evidence.

The Phillips court discussed the views contained in the ATTORNEY GENERAL's Manual on THE ADMINistrative Procedure Act, see note 35 supra, and conceded that that document took "for granted that rate setting hearings under the Gas Act will be on the record and thus will be formal and adjudicative." 475 F.2d at 851-52. However, the court rejected this authority as "weak" since it was directed not to Congress but to the federal agencies subsequent to the enactment of the APA. Id. at 852 .

84. In dissent, Judge Seth argued that the FPC was required to observe formal rulemaking procedures in the promulgation of rates. 475 F.2d at 852-57. Judge Seth noted that the Florida East Coast Ry. case had stated that sections 7 and 8 of the APA could be triggered by other language than the precise words "on the record," and althongh not specifically referring to the NGA's requirement that the Commission's findings be supported by substantial evidence, Judge Seth reasoned that the hearing requirement together with the "contemplated review" were sufficient to trigger formal rulemaking. Id. at 854 . Thus, he concluded that

even if the Natural Gas Act does not expressly reqnire a full evidentiary hear-

ing, it does require a "hearing on the record," and thus if the Administrative

Procedure Act is operative, a hearing to meet its requirements set out in 5

U.S.C. $\$ 556$ and 557 [sections 7 and 8 of the APA] is necessary. Id.

Finally, after disagreeing with the majority's finding that an informal record would allow for adequate judicial review, see note 83 supra, Judge Seth argued that ratemaking, which involves the resolution of disputed facts and "can be [seen as] the confiscation of property of the regulated parties," is more adjudicatory than legislative in nature and thus requires formal adjudicatory procedures. 475 F.2d at 857 ; cf. Justice Douglas' dissent in Florida East Coast Ry., discussed in note 73 supra.

85. 483 F.2d 1238 (D.C. Cir. 1973). 
adhere to the formal requirements of sections 7 and 8 of the APA. ${ }^{80}$ In Mobil, the petitioner, a natural gas producer, challenged the validity of rates established im an informal rulemaking proceeding, claiming, inter alia, that the Commision should have followed the formal rulemaking requirements of the APA. ${ }^{87}$ The court first held that simce the NGA did not specifically require "on the record" rulemaking, the Commission was not bound to strictly observe the formal standards of APA sections 7 and 8, noting that Florida East Coast Railway had "virtually established [that phrase] as a touch-stone test" of when formal rulemaking is required. ${ }^{88}$ However, the court rejected the argument that since sections 7 and 8 were inapplicable, the Commission was free to proceed in accordance only with the less rigorous informal rulemaking procedures outlined in section 4 of the APA. ${ }^{80}$ Rather the court viewed the informal and formal rulemaking procedures of the APA as establishing only minimum and maximum procedural re-

86. Id. at 1264 .

87. Petitioner appealed from an Order Establishing Charges for Transporting Liquids and Liquefiable Hydrocarbons, FPC Order No. 449, 37 Fed. Reg. 2955 (1972).

The Commission had initiated the contested ratemaking proceeding on Feb. 5, 1968 , by anuouncing its intention to adopt a statement of general policy which would allocate an appropriate proportion of costs to the transportation of liquids and liquefiables. Notice of Proposed Statement of General Policy, 33 Fed. Reg. 2860 (1968). Thereafter, the Commission changed the nature of the proceeding to one for the setting of rates. As the Mobil conrt observed, 483 F.2d at 1251 n.39, the Commission probably failed to comply with the notice requirements of section 4 of the APA, for that section requires that notice be giveu of the "terms or substance of the proposed rule or a description of the subjects and issues involved." Thus, the Commission may not even have complied with the requirements of informal rulemaking.

In additiou to the rulemaking question, the other two main issues presented in $\mathrm{MO}$ bil were whether the Commission had jurisdiction to establish rates for liquid and liquefiable hydrocarbons and whether it had unlawfully used privileged data submitted as part of a settlement offer in a prior rate proceeding. Id. at 1246. The court determined that the Commission had jurisdiction over liquefiable but not liquid hydrocarbons. Id. at 1263 . It held that the claim of privilege with respect to the previously submitted data was only available to the party who had made the settlement offer in the prior proceeding, and that since Mobil was not that party, it had no basis to make such a claim. Id. at $1246 \mathrm{n} .12$.

88. 483 F.2d at 1250. Ironically, the Supreme Court in Florida East Coast Ry. noted that words other than "on the record" could trigger formal rulemaking. 410 U.S. at 238 .

89. 483 F.2d at 1251 . The court rejected the syllogistic argument that formal and informal rulemaking were mutually exclusive and the only two forms of procedure permissible under the APA. Id. at 1251 n.40. Compare this conclusion of the Mobil court with the following assertion by Professor Hamilton:

The Administrative Procedure Act is polar with respect to rulemaking procedures: it does not recognize any alternative or intermediate types of procedures between informal rulemaking on the one hand and formal rulemaking on the other (except for the discretionary use of an informal hearing im connection with informal rulemaking). Hamilton, supra note 24 , at 1277 (emphasis added). 
quirements to be followed in agency decision-making. ${ }^{90}$ Thus, the court held that while the nature of a particular agency's statutory scheme inay require less than the formal procedures prescribed by sections 7 and 8 , it may require inore than informal procedures outlimed in section $4^{91}$ The court observed that ratemaking involved "both a legislative policy determination and an adjudicative resolution of disputed facts."92 Since the NGA explicitly requires that the FPC's factual determinations be supported by substantial evidence, ${ }^{93}$ the court reasoned that this requirement necessitates some form of adversary, adjudicative-type procedure. $^{94}$ The court based this conclusion upon

90. 483 F.2d at 1253.

91. The District of Columbia Circuit adopted a similar approach in International Harvester Co. v. Ruckelshaus, 478 F.2d 615 (D.C. Cir. 1973). There the court determined that the "public hearing" provision of the Clean Air Act, 42 U.S.C. $\$ 206(\mathrm{~b})$ (5) (1970), did not require formal rulemaking. Id. at 630 n.48. However, because of the technical complexity of the factual issues in dispute (whether auto and truck manufacturers could meet by 1975 the technological requirements of the Clean Air Act emission standards), the court ordered the EPA to grant "some opportunity for crossexamination." Id. at 649. See Kennecott Copper Corp. v. EPA, 462 F.2d 846, 850 (D.C. Cir. 1972) (holding that in particular cases fairness may require more than the minimuin requirements of informal rulemaking); Joseph E. Seagram \& Sons, Inc. v. Dillon, 344 F.2d 497, 500 (D.C. Cir. 1965) (per curiam) (even where formal rulemaking is not required, courts may fashion procedure to do justice in a particular case); cf. Upjohn Co. v. Finch, 422 F.2d 944, 955 (6th Cir. 1970) (holding that regardless of whether the statute required rulemaking or adjudication, an evidentiary hearing was required when "a genuine and substantial issue of fact" was raised by means of an offer of proof). See also Walter Holm \& Co. v. Hardim, 449 F.2d 1009, 1015-16 (D.C. Cir. 1971).

92. $483 \mathrm{~F} .2 \mathrm{~d}$ at 1257.

93. 15 U.S.C. $\& 717 \mathrm{r}$ (b) (1966). For a general discussion of the substantial evidence test, see Jaffe, Judicial Review: "Substantial Evidence on the Whole Record," 64 HARV. L. REv. 1233 (1951).

94. The court elaborated on this rationale in the following manner:

The degree of fact dispute resolution necessary in a particular proceeding is directly related to the degree of evidentiary support required by Congress $\mathrm{im}$ establishing a factual basis for a proposed rate. If a relatively high degree of evidentiary support is required in establishing a factual predicate, the rulemaking procedures must be designed to create this. $483 \mathrm{~F} .2 \mathrm{~d}$ at 1257 .

The Mobil court distinguished the Supreme Court's holding in Florida East Coast Ry. on the grounds that the Interstate Commerce Act, 49 U.S.C. \$ 1 et seq. (1970), construed in that case, does not require that factual determinations made in ratemaking proceedings be supported by substantial evidence. See notes 33, 71 \& 73 supra and note 95 infra and accompanying text. Rather, the court observed that the ICC statute provides mereiy that "the Commission shall give consideration to the various aspects of the railroad industry." 483 F.2d at 1260, citing Umited States v. Florida East Coast Ry., 410 U.S. 22A, 246 (1973) (emphasis in original). On the basis of these observations, the court conciuded that

[t] ] "consideration" test obviously permits the ICC much greater leeway and requires much less certainty than does the "substantial evidence" test. It is entirely appropriate that the procedures for "consideration" of evidence would exploy almost none of the dispute resolution procedures ordinarily associated with adjudication. Under these circumstances prevailing in Florida 
the nature of the substantial evidence test which requires that a reviewing court find sufficient evidence in the record to support the agency's findings. The court stressed that

the rule that the "whole record" be considered-both evidence for and against-means that the procedures must provide some mechanism for interested parties to introduce adverse evidence and criticize evidence introduced by others. ${ }^{95}$

The court concluded that notice and comment informal rulemaking was insufficient to create a record which satisfies the substantial evi-

East Coast, the informal procedures could be more than adequate. Id. at 1260-61.

Thus, it is clear that the court rejected the argument that since prescription of rates "is, in legal and practical effect, a directive taking money from the hands of one private person and placing those funds directly into the hands of another private person," ratemaking by informal rulemaking is inconsistent with due process requirements. Reply Brief for Petitioner Mobil Oil Corp. at 13. See notes 73, 84 supra discussing respectively the disseut of Justice Douglas in Florida East Coast Ry. and that of Judge Seth in Phillips. The petitioner in Mobil bitterly characterized the FPC's einployment of informal ratemaking as

a reversion to the dark ages of administrative law which predated the APA, aud in which an agency and selected individuals privately decided on rates, no public record was developed, and the results were imposed on the ratepayer without service of materials used or an opportunity to have any meaningful participation. Brief for Petitioner Mobil Oil Corp. at 26.

95. 483 F.2d at 1258 (original in italics). The court elaborated its view that informal rulemaking procedures are inherently inconsistent with the substantial evidence test.

Informal comments simply cannot create a record that satisfies the substantial evidence test. Even if controverting information is submitted in the form of comments by adverse parties, the procedure employed cannot be relied upon as adequate. A "whole record," as that phrase is used in this context, does not consist merely of the raw data introduced by the parties. It includes the process of testing and illumination ordinarily associated with adversary, adjudicative procedures. Without this critical element, informal comments, even by adverse parties, are two halves that do not make a whole. Thus, it is adversary procedural devices which permit testing and elucidation that raise information from the level of mere inconsistent data to evidence "substantial" enough to support rates. Id. at 1260 .

Thus, the court felt that the record required for application of the substantial evidence test was inextricably intertwined with the procedures employed to develop that record. Cf. Texas Gulf Coast Area Natural Gas Rate Cases, 487 F.2d 1043, 1069 (D.C. Cir.), petition for cert. filed, 42 U.S.L.W. 3387 (U.S. Dec. 21, 1973) (No. 73-969), where Judge Leventhal, who had joined in the Mobil opinion, states that the substantial evidence test reflects "a congressional intent to limit agency determinations to record evidence," notwithstanding the procedures used to compile such record. In Universal Camera Corp. v. NLRB, 340 U.S. 474, 487-88 (1951), the Supreme Court held that the substantial evidence test required that courts base their review on the entire record considered by the agency. Simce an agency conducting informal rulemaking may rely upon extra-record factors, such procedures are apparently inadequate for NGA ratemaking. See generally 4 K. DAvis $\$ \$ 29.02-.03$. For critical views of the Mobil court's interpretation of the significance of the substantial evidence requirement, see Wright, Tlle Courts and the Rulemaking Process: the Limits of Judicial Review, 59 CoRNelL L. REv. 375, 383 n.34 (1974); Note, The Judicial Role in Defining Procedural Requirements for Agency Rulemaking, 87 HARV. L. Rev, 782, 803-05 (1974). 
dence test. While the court did not require that the FPC adhere strictly to the formal procedures provided in sections 7 and 8 , and although the court suggested various methods which the Commission could employ to eliminate some of the more cumbersome burdens of a formal trial-type adjudication, ${ }^{96}$ it made clear that an adjudicatory procedure of some nature was essential to create an evidentiary record and thus is required in FPC ratemaking proceedings.

\section{COMPaRISON OF Phillips AND Mobil}

The decisions of the Tenth Circuit in Phillips and the District of Columbia Circuit in Mobil are obviously in conflict. ${ }^{87}$ The inconsistency may be ascribed in large part to the radically different views which each court displayed toward both the degree of procedural discretion granted to the FPC under the NGA and the proper apphication of the rulemaking provisions of the APA. In its examination of the NGA the Phillips court focused upon sections 15 and 16, which provide respectively that FPC hearings are to be governed by procedures adopted by the Commission ${ }^{98}$ and that the Commission may prescribe all rules that it finds "necessary and appropriate."99 Construing the above provisions in light of the broad dicta in Permian, which suggest

96. The court ordered the Commission to use procedures that would "adequately test" its factual determinations and create a record permitting review. 483 F.2d at 1262. This requires adversary procedures but not necessarily oral cross-examination. To indicate an alternative, the court referred to its decision in International Harvester, see note 91 supra, in which it approved of the EPA's use of screened written interrogatories. 483 F.2d at 1263.

As another means of streamlining a trial-type proceeding, the court suggested that the FPC incorporate evidence from another rate proceeding. In order to do so, however, the court stated that it had to give affected parties notice and opportunity to comment. It had to incorporate all evidence on a particular point, and not just that which supported its conclusions. Finally, it could only adopt factual assertions which had been subject to examination and testing by opposing parties. Id. at 1263 n.93. See also Texas Gulf Coast Area Natural Gas Rate Cases, 487 F.2d 1043 (D.C. Cir.), petition for cert. filed, 42 U.S.L.W. 3387 (U.S. Dec. 21, 1973) (No. 73-969) (holding that the FPC could not charge parties to one proceeding with knowledge of the contents of the record in other proceedings without notice and opportunity to challenge the incorporated evidence.)

97. Although Phillips involved proposed procedures for the fixing of maximum area rates for the sale of natural gas, while Mobil considered procedures enployed in establishing minimum rates required to be charged by natural gas pipelines for the transportation of certain by-products of natural gas, such rates are each promulgated pursuant to the FPC's mandate under section 4(a) of the NGA to establish "just and reasonable rates for the transportation and sale of natural gas traveling in interstate commerce." 15 U.S.C. $\$ 717 \mathrm{c}(\mathrm{a})(1970)$.

98. 15 U.S.C. $\$ 717 \mathrm{n}(1970)$.

99. Id. $\$ 7170$. 
the need for innovative and expeditious FPC procedures, ${ }^{100}$ the Phillips court concluded that the NGA does not bar the Commission's use of informal rulemaking procedures to establish rates under the Act. ${ }^{101}$ In contrast, the Mobil court stated that section 16 cannot be read to give the Commission a "carte blanche" in its clioice of procedures. ${ }^{102}$ Rather, Mobil held that the degree of flexibility permitted by the vague language in that section is limited by the requirement that the FPC's factual predicates for a proposed rate be supported by substantial evidence. ${ }^{103}$ Whereas the Phillips opinion completely ignored the substantial evidence requirement, the Mobil court found this requirennent virtually dispositive of the issue before it, concluding that the requirement mandates soine form of "adversary, adjudicative-type procedures" which are not supplied by informal rulemaking. ${ }^{104}$ Rejecting a broad interpretation of the dicta in Permian, the Mobil court observed that the decision had inerely approved the use of area rather than individual rate proceedings. ${ }^{105}$ Since the area rates established in the Permian proceeding had been established pursuant to adjudicatory procedures, Permian could not, in the Mobil court's view, be read to support ratemaking through informal ruleinaking procedures. ${ }^{100}$ In summation, the Phillips court read the NGA and the Permian decision as providing the Commission with procedural discretion sufficiently broad to authorize informal ratemaking procedures, while the Mobil court concluded that such discretion is severely constrained by the

100. See notes 17-19 supra and accoinpanying text.

101. 475 F.2d at 850 . Indeed, the Phillips majority characterized the Permian decision as "dispositive" of the question whether the FPC may establish rates by informal rulemaking. Yet, as noted earlier, Permian did not address that precise issue. See text accompanying notes 17-19 supra.

102. 483 F.2d at 1255. The Eighth Circuit has taken a similar position in holding that section 16 of the NGA "is not an enlargement of the specific authority granted the Commission under $\S \S 4,5$ and 7 of the Act." Murphy Oil Co. v. FPC, 431 F.2d 805, 810 (8th Cir. 1970). See New England Power Co. v. FPC, 467 F.2d 425, 43031 (D.C. Cir. 1972), cert. granted, 411 U.S. 981 (1973). See also Shell Oil Co. v. FPC, 334 F.2d 1002 (3d Cir. 1964); Public Serv. Coinm'n v. FPC, 327 F.2d 893 (D.C. Cir. 1964); Willmet Gas \& Oil Co. v. FPC, 294 F.2d 245 (D.C. Cir. 1961); Mississippi River Fuel Corp. v. FPC, 202 F.2d 899 (3d Cir. 1953).

The Mobil court did not specifically refer to section 15 of the NGA. However, it would appear that the court's conclusion that the "substantial evidence" requirement placed significant restraints on the FPC's choice of ratemaking procedures would also serve to limit the language contained in that section. See note 95 supra and accompanying text.

103. 483 F.2d at 1258.

104. Id. at 1259. See notes 94,95 supra.

105. Id. at $1256 \mathrm{n} .62,1262$ n.89.

106. Id. The Mobil court specifically observed that Permian did not condone "a contraction of procedures." Id. at 1256 n.62. 
congressional insertion in the NGA of the substantial evidence requirement.

The two courts also took sharply divergent approaches in their application of the provisions of the NGA to the rulemaking sections of the APA. The Phillips court initially noted that the APA defines ratemaking as a rulemaking function. ${ }^{107}$ The court further observed that under the APA rulemaking is conducted pursuant to informal notice and comment procedures unless "required by statute to be made on the record."108 Simce the NGA does not contain the words "on the record," the court concluded that formal rulemaking did not apply. ${ }^{109}$ Although the Mobil court reached a similar conclusion, it rejected the rationale implicit in the Phillips opimion, namely, that since a lack of "on the record" language in the APA precluded invocation of strict formal rulemaking procedures, the FPC is free to establish rates by informal rulemaking. ${ }^{110}$ Thus, while the Phillips opinion reveals a view of the APA as permitting only two procedures for rule promulgation, i.e., formal and informal, ${ }^{111}$ the Mobil decision portrays the APA "as providing the outer boundaries of administrative procedures."112 In this view the informal procedures of section 4 are seen as prescribimg the minimum protection which must be afforded to interested parties, while the formal procedures set forth im sections 7 and 8 provide the maximum protection to be given such parties. ${ }^{113}$ Hence, the court reasoned that a particular agency's statute may well require more rigorous procedures than those outlined in section 4 of

107. 475 F.2d at 851 . See notes 22,51 supra.

108. Id. at 851 . See note 83 supra.

109. Id. Several other courts in 1973 concurred in this interpretation that the lack of the words "on the record" in the regulatory statute is a strong argument against formal rulemaking. See Anaconda Co. v. Ruckelshaus, 482 F.2d 1301 (10th Cir. 1973); Duquesne Light Co. v. EPA, 481 F.2d 1, 6 n.26 (3d Cir. 1973); Buckeye Power, Inc. v. EPA, 481 F.2d 162, 173 n.5 (6th Cir. 1973); Delaware Citizens for Clean Air, Iuc. v. Ruckelshaus, 480 F.2d 972 (3d Cir. 1973); International Harvester Co. v. Ruckelshaus, 478 F.2d 615, 630 n.48 (D.C. Cir. 1973).

110. The Mobil court rejected as syllogistic the argunent that either formal or informal ruleinaking apphes, depeuding upon whether the statute contains the words "on the record." Concurrently, the court rejected the contention that the APA does not allow for an intermediate procedure. $483 \mathrm{~F} .2 \mathrm{~d}$ at $1251 \mathrm{n} .40$. See note 96 supra and accompanying text. But see Note, supra note 95 , at 803-04.

111. 475 F.2d at 851 .

112. 483 F.2d at 1253 . The Mobil court held that informal and formal rulemaking were the minimum and inaximum protections allowed under the APA, but that "[t]here is no reason ... to conclude that Congress in estabhishing these limits intended to preclude all the possible formulations that might lie in between the two extremes." Id.

113. See note 112 supra. 
the APA but not demand strict compliance with the formal adjudicatory procedures found in sections 7 and $8 .{ }^{114}$ Consequently, the Mobil court found that the substantial evidence requirement contained in the NGA, while insufficient to mvoke the formal rulemaking procedures of sections 7 and 8 , precludes utilization of informal rulemaking in the proinulgation of rates.

\section{CONCLUSTON}

It is subinitted that the decision in Mobil, holding that the FPC may not establish rates by informal rulemaking, properly construed the application of the NGA to the rulemaking provisions of the APA. In concluding that a lack of "on the record" language in the NGA strongly suggests that the formal ruleinaking provisions of sections 7 and 8 of the APA are inapphicable, the Phillips court purportedly followed the Supreme Court's decisions in Allegheny-Ludlum and Florida East Coast Railway. However, the ICC statute involved in those cases did not contain a requirement that agency findings be supported by substantial evidence. While the Mobil court correctly perceived that this requirement presupposes some type of adjudicative procedures, ${ }^{115}$ the Phillips court completely disregarded the statutory requirement's existence, mucli less its significance. Moreover, the Mobil court properly held that an agency statute may require more procedures than those outlined in the informal rulemaking provisions of section 4 of the APA, yet not extend so far as to demand strict compliance with the formal procedures prescribed by sections 7 and 8..$^{116}$

Ratemaking by informal rulemaking represents the latest effort by the FPC to develop procedures which will allow it to more efficiently and expeditiously effectuate its moinentous task of regulatimg the natural gas industry. As the Permian decision suggests, "the breadth and complexity of the Commission's responsibilities demand that it be given every reasonable opportunity to formulate methods of regulation appropriate for the solution of its intensely practical difficul-

114. 483 F.2d at 1250 . See notes 94,95 supra and accompanying text.

115. See notes 94,95 supra and accompanying text. See generally Scalia \& Goodman, Procedural Aspects of the Consumer Product Safety Act, 20 U.C.L.A.L. REv. 899, 934-35 (1973).

116. The APA specifically provides that its provisions "do not limit or repeal additional requirements imposed by statute or otherwise recognized by law." 5 U.S.C. $\S 559$ (1970). The Supreme Court observed in United States v. Florida East Coast Ry., 410 U.S. 224 (1973), that "any agency is free under the Act to accord litigants appearing before it more procedural rights than the Act requires ...." Id. at 236 n.6. 
ties."117 Yet, as the Mobil decision recognizes, this flexibility is not without limitations. The establishment of just and reasonable rates for the sale and transportation of natural gas requires the resolution of highly complex and often disputed issues of fact. The drafters of the NGA expressed their awareness of this significant aspect of the ratemaking process by requiring that findings of fact in ratemaking proceedings be supported by substantial evidence. The Mobil decision correctly impleinents this congressional intent by requiring the FPC to employ ratemaking procedures which will develop the evidentiary record necessary for a proper application of the substantial evidence test. ${ }^{118}$

Despite the foregoing conclusion, it may be argued that the Mobil court erred in not specifically requiring that the FPC conduct ratemaking proceedings pursuant to the formal ruleinaking provisions of sections 7 and 8 of the APA. As noted above, the Mobil court relied heavily upon the lack of the specific words "on the record" in the NGA in concluding that the formal rulemaking procedures of the APA do not apply to FPC rateınaking. ${ }^{119}$ However, the Supreme Court in Allegheny-Ludlum and Florida East Coast Railway specifically stated that formal rulemaking may be triggered by other statutory language having the saine meaning. ${ }^{120}$ Consequently, it may be argued that the provisions of the NGA which require that rates be established after a hearing, ${ }^{121}$ together with those requiring that the Coinmission's findings be supported by substantial evidence in the "record

117. 390 U.S. at 790.

118. Judge Wright has strongly criticized the Mobil court's "ad hoc" approach to rulemaking procedures, contending that "it flies in the face of the APA." Wright, supra note 95 , at 397 . He argues that

[i]f reviewing courts ignored the guidance of section 553 and instead operated under a vague injunction to find those procedures "best" suited to each agency action presented, judicial review of rulemaking would become totally unpredictable.

The administrative response would, however, be completely predictable. Fearing reversal of his substantive mitiatives, each administrator would clothe his agency's actions in the full wardrobe of adjudicatory procedure. By demanding procedural refimements, on an ad hoc basis, reviewing courts would inadvertently induce agencies to adopt maximuin procedures in all cases. Id. at 387-88.

Judge Wright's analysis ignores the fact that a particular administrative statute, such as the NGA, may prescribe additional procedural requirements more rigorous than those set forth in the informal rulemaking provisions of the APA. See note 116 supra.

119. See notes 110,118 supra and accompanying text.

120. United States v. Florida East Coast Ry., 410 U.S. 224, 238 (1973); United States v. Allegheny-Ludlum Steel Corp., 406 U.S. 742, 757 (1972).

121. 15 U.S.C. $\$ \$ 717 \mathrm{c}-\mathrm{d}(1970)$. 
upon which the order . . . was entered,"122 are essentially the equivalent of an "on the record requirement." ${ }^{23}$ Since the Mobil court determined that the above language mandated some type of adjudicatory procedures, it would seen preferable for the court to have concluded that the formal procedures specifically provided by Congress should apply rather than allowing the FPC to develop its own form of adjudicatory procedures. ${ }^{124}$ Congress enacted the APA in order to establish uniform procedural standards to be followed by administrative agencies. Therefore, it would seem consistent with the purpose which underlies the Act to require agencies to adhere to those procedures, especially since the NGA does not specifically delineate an alternative procedure. For this reason, it is submitted that the proper judicial resolution with regard to the appropriate procedures to be followed in FPC ratemaking is to require the Commission to establish rates pursuant to the formal "on the record" procedures provided in the APA. ${ }^{25}$

122. Id. $\S 717 \mathrm{r}(\mathrm{b})$.

123. See Attorney General's manual on the Administrative Procedure Act, note 35 supra.

124. Such a result would not necessarily deprive the Commission of the flexibility to adjust its procedures to fit the needs of a particular proceeding. Section 7(d) of the APA, 5 U.S.C. $\$ 556$ (d) (1970), provides that

[i]n rule making .... an agency may, when a party will not be prejudiced thereby, adopt procedures for the submission of all or part of the evidence in written form.

Judge Friendly has observed that this provision reveals a congressional intention that "even when rulemaking had to be done by a hearing 'on the record,' the record did not always have to be made in the traditional manner." Long Island R.R. v. United States, 318 F. Supp. 490, 498 (E.D.N.Y. 1970). See also Texas Gulf Coast Area Natural Gas Rate Cases, 487 F.2d 1043, 1069 n.59 (D.C. Cir.), petition for cert. filed, 42 U.S.L.W. 3387 (U.S. Dec. 21, 1973) (No. 73-969).

In sum, since it appears that formal rulemaking is sufficiently flexible to incorporate the procedures suggested by the Mobil court, see note 69 supra, a more proper course for that court to have followed might have been to have required the FPC to comply with the requirements of formal rulemaking, as modified by the flexibility afforded by section 7(d) of the APA.

125. 5 U.S.C. $\$ \S 553(c), 55,57$ (1970). 